\title{
KARAKTERISTIK PEMBAKARAN BIOBRIKET CAMPURAN AMPAS AREN, SEKAM PADI, DAN BATUBARA SEBAGAI BAHAN BAKAR ALTERNATIF
}

\author{
Joko Triyanto, Subroto, Marwan Effendy \\ Teknik Mesin Universitas Muhammadiyah Surakarta \\ J1. A. Yani Tromol Pos 1 Pabelan, Kartosura \\ Email :subroto@ums.ac.id
}

\begin{abstract}
ABSTRAK
Biomassa (ampas aren dan sekam padi) merupakan bahan hayati yang biasanya dianggap sebagai sampah dan sering dimusnahkan dengan cara dibakar. Biomassa yang berasal dari limbah pertanian ini menjadi masalah umum didaerah pedesaan karena mengganggu lingkungan. Sehingga perlu dilakukan penelitian yang mampu untuk mengurangi pencemaran lingkungan yang terjadi, dengan menjadikan biomassa (ampas aren dan sekam padi) sebagai bahan dasar biobriket

Penelitian ini diawali dengan pengumpulan bahan dasar berupa ampas aren, sekam padi, dan batubara, serta aspal sebagai bahan perekat, setelah itu dilakukan uji proximate bahan dasar. Pembuatan biobriket dengan komposisi 100\% ampas aren; $100 \%$ sekam padi;40\%ampas aren,40\% sekam padi,dan 20\% batubara;30\% ampas aren, 30\% sekam padi, dan 40\% batubara; 20\% ampas aren, 20\% sekam padi, dan 60\% batubara;dan 100\% batubara serta bahan perekat aspal 10\% dari berat total biobriket. Biobriket dibuat dengan berat 5 gram. Setelah itu dilakukan pengujian karakteristik pembakaran, yang meliputi penurunan massa, laju pembakaran, dan temperatur pembakaran biobriket.

Hasil penelitian menunjukkan bahwa temperatur tertinggi pembakaran dihasilkan oleh biobriket dengan komposisi 100\% batubara. Hal ini menunjukkan bahwa semakin besar komposisi batubara, maka temperatur biobriket yang dihasilkan semakin tinggi. Tingginya kadar karbon pada batubara akan membuat temperatur puncak yang akan dicapai semakin lama. Sedangkan penurunan massa paling cepat terjadi pada komposisi $100 \%$ ampas aren dan 100\% sekam padi, hal ini dikarenakan ampas aren dan sekam padi mempunyai volatile matter tinggi sehingga menyebabkan mudah terbakar.
\end{abstract}

Kata kunci : Batubara, Ampas aren, Sekam padi, Biobriket

\section{PENDAHULUAN}

Biomassa merupakan bahan hayati yang biasanya dianggap sebagai sampah dan sering dimusnahkan dengan cara dibakar. Biomassa yang berasal dari limbah pertanian selama ini menjadi masalah umum didaerah pedesaan karena mengganggu lingkungan. Sebagai contohnya adalah ampas aren dan sekam padi.

Ampas aren merupakan hasil samping pemerahan batang pohon aren muda yang diambil tepungnya. Setelah batang pohon aren diambil tepungnya maka yang sisa hanya ampasnya yang tidak dapat digunakan.

Sekam padi merupakan hasil samping dari proses penggilingan padi. Diperkirakan saat 
ini penggunaan sekam padi belum maksimal masih sebatas pada beberapa hal seperti untuk campuran makanan ternak dan bahan bakar pembuatan batubata, sedangkan produksi padi di Indonesia semakin banyak.

Disisi lain, Indonesia memiliki cadangan batubara yang cukup besar untuk memasok energi selama ratusan tahun. Namun selama ini batubara hanya menyumbang sekitar $14 \%$ dari total konsumsi energi nasional, jauh dibawah permintaan BBM. Situasi tersebut mengakibatkan produksi batubara dalam negeri kurang optimal [1].

\section{BATASAN MASALAH}

Dalam penelitian ini masalah yang diteliti adalah kandungan bahan dasar dan karakteristik pembakaran biomassa $100 \%$ ampas aren dan $100 \%$ sekam padi,biobriket campuran $40 \%$ ampas aren, $40 \%$ sekam padi, $20 \%$ batubara; $30 \%$ ampas aren,30\% sekam padi, $40 \%$ batubara;dan $20 \%$ ampas aren, $20 \%$ sekam padi, $60 \%$ batubara; serta $100 \%$ briket batubara, dengan bahan perekat aspal.

\section{TUJUAN PENELITIAN}

Tujuan dari penelitian yang dilakukan ini adalah:

a. Membuat biobriket campuran ampas aren, sekam padi, dan batubara.

b. Menguji karakteristik pembakaran biobriket.

c. Meneliti sifat dasar bahan biobriket.

\section{TINJAUAN PUSTAKA}

Tekmira [1] telah menghasilkan produk unggulan berupa biobriket yang terbuat dari $76 \%$ batubara, 19\% biomass dan 5\% kapur. Biobriket ini memiliki keunggulan lebih mudah dinyalakan dan digunakan, asap dan emisi gasnya lebih sedikit, serta menghasilkan panas dengan suhu relatif tinggi.

Rahman, 2005 [2] meneliti briket sekam padi dan arang dengan komposisi arang 70\%, $60 \%$ dan 50\%, mengatakan briket dengan komposisi 50\% sekam padi dan 50\% arang kayu mempunyai penurunan massa paling cepat saat pembakaran. Hal ini disebabkan kadar volatile matter pada sekam padi lebih tinggi dibandingkan arang kayu. Dari penelitian ini dapat disimpulkan bahwa kadar volatile matter berpengaruh dalam pembakaran.

\section{DASAR TEORI}

\section{Batubara $[3,4]$}

Batubara adalah mineral organik yang dapat terbakar, terbentuk dari sisa tumbuhan purba yang mengendap, yang selanjutnya berubah bentuk akibat proses fisika dan kimia yang berlangsung selama jutaan tahun. Faktor tumbuhan purba yang jenisnya berbeda-beda sesuai dengan zaman geologi dan lokasi tempat tumbuh dan berkembangnya, ditambah dengan lokasi pengendapan (sedimentasi) tumbuhan, pengaruh tekanan batuan dan panas bumi serta perubahan geologi yang berlangsung kemudian, akan menyebabkan terbentuknya batubara yang jenisnya bermacam-macam. Proses awalnya, endapan tumbuhan berubah menjadi gambut (peat), yang selanjutnya berubah menjadi batubara muda (lignit) atau disebut juga batubara coklat (brown coal). Setelah mendapat pengaruh suhu dan tekanan yang terusmenerus selama jutaan tahun, maka batubara muda akan mengalami perubahan yang secara bertahap menambah maturitas organiknya dan mengubah batubara muda menjadi batubara sub bituminus (sub bituminous). Perubahan kimiawi dan fisika terus berlangsung hingga batubara menjadi lebih keras dan warnanya lebih hitam, sehingga membentuk bituminus (bituminous) atau antrasit (anthracite). Dalam kondisi yang tepat, peningkatan maturitas organik yang semakin tinggi terus berlangsung hingga membentuk antrasit. 
2. Pembakaran Batubara $[3,4]$

Beberapa tahapan dalam pembakaran batubara adalah sebagai berikut:

a. Pengeringan

Pengeringan merupakan tahap awal proses pembakaran batubara. Dalam proses ini batubara mengalami proses kenaikan temperatur yang akan mengakibatkan menguapnya kadar air yang berada pada permukaan batubara itu, sedangkan kadar air yang berada di dalam akan menguap melalui pori-pori batubara tersebut.

b. Devolatilisasi

Devolatilisasi adalah proses batubara mulai mengalami dekomposisi setelah terjadi pengeringan. Proses dekomposisi merupakan peristiwa pecahnya ikatan kimia secara thermal dan volatile matter (yang merupakan hasil proses devolatilisasi) keluar dari partikel.

c. Pembakaran Arang

Sisa dari pirolisis adalah arang (fix carbon) dan sedikit abu.

\section{Faktor-faktor yang Mempengaruhi Pembakaran Batubara [3,4]}

Dalam proses pembakaran batubara terdapat faktor-faktor yang mempengaruhi pembakaran batubara, antara lain:

a. Ukuran Partikel

b. Kecepatan Aliran Udara

c. Jumlah Udara Pembakaran

d. Temperatur Udara Pembakaran

e. Karakteristik Batubara, yang terdiri dari: Kadar Air, Kadar Abu, Zat-zat yang mudah menguap (Volatile Matter), Kadar Kalori dan Temperatur penyalaan

\section{Ampas Aren}

Aren merupakan tumbuhan berbiji tertutup dimana biji buahnya terbungkus daging buah. Pohon Aren banyak terdapat di seluruh wilayah Indonesia.

Dari hasil proses pengolahan aren, maka dihasilkan hasil sisa/ limbah yang berupa:

a. Ampas Serbuk

Limbah serbuk yang diperoleh dari serbuk yang sudah diambil tepungnya. Serbuk tersebut dapat dipisah-pisahkan menjadi 3 macam, yaitu serbuk-serbuk kecil, serbukserbuk besar dan serat-serat panjang. Dari ketiga jenis serat dan serbuk tersebut dapat digunakan sebagai bahan bakar.

b. Kulit Batang

Seperti diketahui bahwa yang mengandung tepung adalah empulur batang pohon aren, sehingga batang pohon aren yang sudah diambil empulurnya tinggal kulit dalam dan kulit luar batang.

\section{Sekam Padi}

Sekam atau kulit terluar dari gabah masih dianggap sampah dan belum dimanfaatkan secara optimal. Di tiap penggilingan padi (huler) masih sering terlihat bertumpuk hingga membukit sekam padi. Sampai saat ini pemanfaatan terbesar sekam adalah sebagai pengisi dan pembakar bata merah yang merupakan industri rakyat di pedesaan pada saat musim paceklik atau kemarau panjang. Industri penggilingan padi yangada di Indonesia mampu mengolah lebih dari 40 juta ton gabah menjadi beras giling dengan rendemen $66-80 \%$. Bila kondisi ini berjalan sesuai dengan kapasitasnya, terdapat sekam yang dapat mengganggu lingkungan sebesar 8 juta ton. Angka ramalan (Aram II) tahu 2004 BPS memperkirakan jumlah produksi gabah kering giling (GKG) sebanyak 53,7 juta ton atau setara dengan 33,92 
ISSN: 1411-4348

juta ton beras dan sekitar 10,7 juta ton sekam.

\section{METODOLOGI PENELITIAN}

Diagram Alir Penelitian

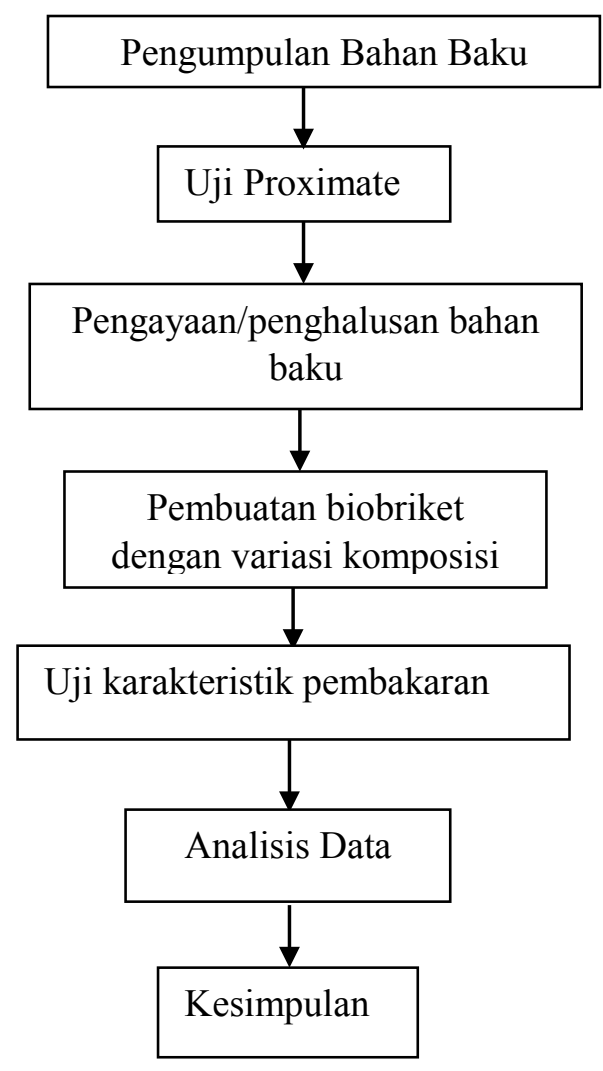

Gambar 1. Diagram alir penelitian

\section{Bahan Penelitian}

Dalam penelitian karakteristik pembakaran biobriket, bahan yang dipergunakan meliputi:

1. Batubara

2. Ampas aren

3. Sekam Padi

4. Aspal, sebagai bahan perekat.

\section{Alat- alat Penelitian}

1. Alat-alat yang digunakan dalam penelitian ini adalah :

2. Alat penghalus batubara

3. Alat penghalus sekam padi (blender)

4. Alat pengepres biobriket

5. Timbangan digital

6. Tungku pembakaran

7. Anemometer digital

8. Thermocouple dan thermocouple digital 


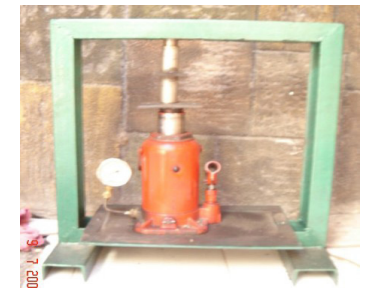

(1)

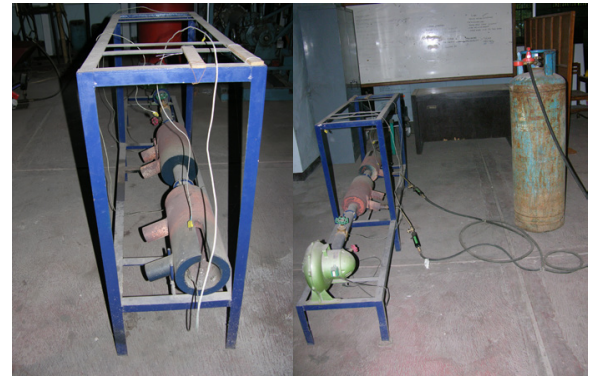

(3)

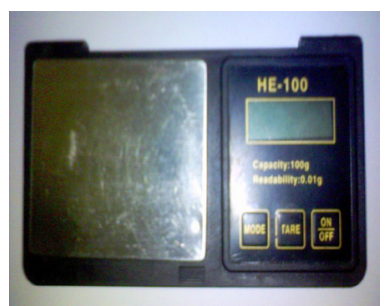

(2)

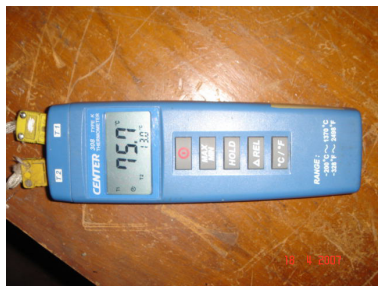

(4)

Gambar 2. (1) Alat pengepres biobriket, (2) Timbangan digital, (3) Tungku pembakaran, dan (4) Termocouple digital

\section{Jalannya Penelitian}

1. Penelitian ini merupakan penelitian eksperimental yang dilakukan dengan uji laboratorium dengan tahap penelitian sebagai berikut :

2. Tahap pertama adalah pengumpulan bahan baku. Bahan baku yang digunakan dalam penelitian ini adalah ampas aren, sekam padi, dan batubara.

3. Tahap kedua adalah pengujian kandungan bahan dasar dengan uji proximate. Pengujian ini dilakukan di Laboratorium Pusat Studi Pangan dan Gizi UGM.

4. Tahap ketiga adalah pembuatan biobriket untuk penelitian.Biobriket dibuat bentuk silinder dengan diameter $28 \mathrm{~mm}$ dan berat 5 gram untuk uji pembakaran

5. Tahap keempat adalah Pengujian pembakaran. Pengujian pembakaran adalah membakar biobriket didalam tungku pembakaran. Data penelitian yang dicatat adalah temperatur benda uji didalam tungku dan penurunan massanya. Pengambilan data ini dilakukan setiap 2 menit sekali sampai tidak mengalami pengurangan massa lagi selama beberapa menit (konstan).

\section{HASIL DAN PEMBAHASAN}

1. Hasil Pengujian Kandungan Bahan Dasar

Tabel 1. Hasil Pengujian sifat bahan dasar

\begin{tabular}{lccc}
\hline \multicolumn{1}{c}{ Sifat } & Batubara & Ampas aren & Sekam padi \\
\hline Kadar air (\%) & 2,89 & 13,41 & 10,25 \\
Kadar abu (\%) & 3.6 & 1,78 & 15,93 \\
Kadar karbon (\%) & 74,43 & 2,68 & 4,43 \\
Volatile matter(\%) & 19,08 & 82,13 & 69,39 \\
\hline Nilai kalori (kal/kg) & 6449,69 & 3296,8 & 3386,3
\end{tabular}


Dari tabel 1. dapat dilihat perbandingan antara sifat dasar ampas aren, sekam padi, dan batubara yang dapat dijadikan bahan bakar. Tabel1. menunjukkan bahwa nilai volatile matter ampas aren dan sekam padi lebih tinggi dibandingkan dengan batubara, sehingga ampas aren dan sekam padi lebih mudah terbakar. Karena kadar volatile matter yang tinggi akan memudahkan proses pembakaran atau titik nyala lebih rendah.

Nilai kalor tertinggi dimiliki oleh batubara, sedangkan untuk ampas aren dan sekam padi memiliki nilai kalor yang lebih rendah, nilai kalor ini akan berpengaruh besar terhadap temperatur pembakaran. Semakin tinggi nilai kalor, maka semakin tinggi pula temperatur yang dihasilkan.

\section{Hasil Pengujian Pembakaran}

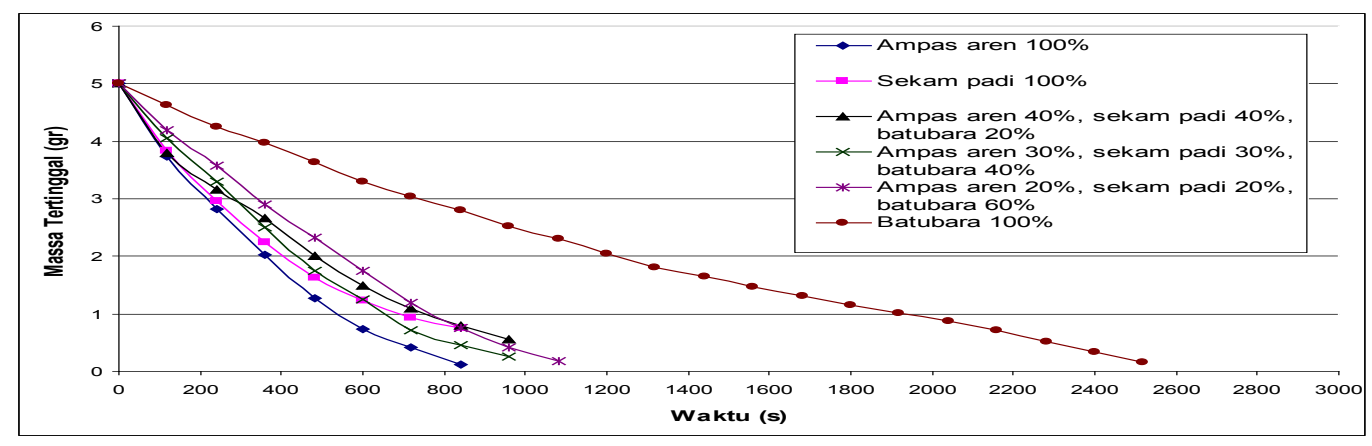

Gambar 3. Grafik hubungan penurunan massa dengan waktu

Dari gambar 3. terlihat bahwa terdapat perbedaan untuk campuran biomassa (ampas aren dan sekam padi) dengan batubara. Semakin banyak kandungan biomassa (ampas aren dan sekam padi) didalam biobriket, maka semakin cepat penurunan massanya. Hal ini jelas terlihat pada biobriket berbahan 100\% ampas aren dan 100\% sekam padi, karena nilai volatile matter yang terkandung di dalam komposisi 100\% ampas aren dan 100\% sekam padi cukup besar sehingga menyebabkan biobriket mudah menyala dan cepat terbakar habis.

Untuk komposisi 100\% batubara penurunan massanya paling lama, hal ini dikarenakan tingginya nilai fixed karbon yang dimiliki oleh batubara, sehingga proses pembakrannya memerlukan waktu yang lama.

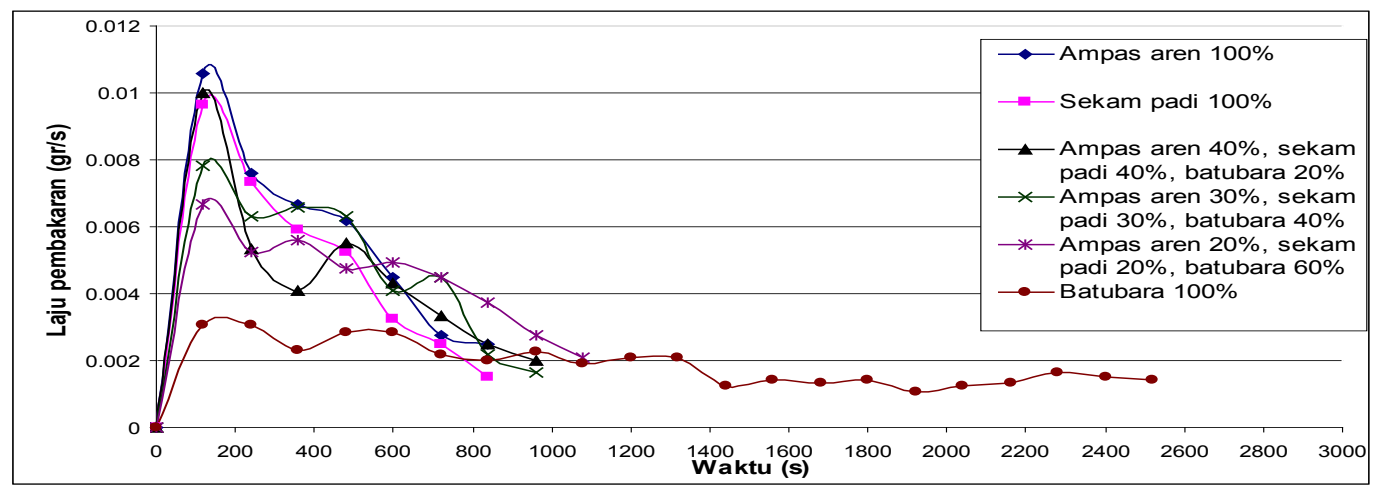

Gambar 4. Grafik hubungan laju pembakaran dengan waktu

Dari gambar 4. terlihat bahwa biobriket dengan campuran 100\% ampas aren dan $100 \%$ sekam padi mempunyai laju pembakaran yang tinggi. Ini disebabkan massa yang tercampur pada komposisi tersebut mudah sekali terbakar, karena mengandung nilai volatile matter yang tinggi, sedangkan pada komposisi $100 \%$ batubara laju pembakarannya rendah. Ini 
disebabkan kadar fixed carbon dalam batubara besar dan nilai volatile matter yang rendah, sehingga biobriket akan semakin sulit terbakar dan memakan waktu yang cukup lama.

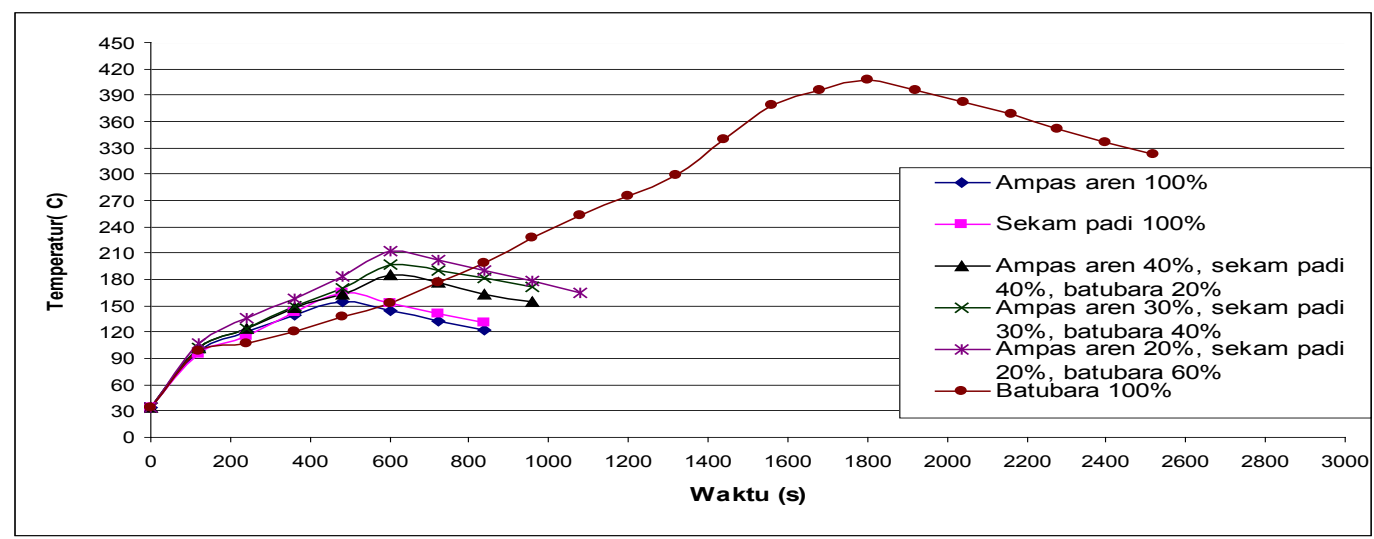

Gambar 5. Grafik hubungan temperatur pembakaran dengan waktu

Dari gambar 5. terlihat bahwa temperatur pembakaran tertinggi terjadi pada komposisi $100 \%$ batubara. Hal ini disebabkan batubara mempunyai nilai kalori yang tinggi dibandingkan ampas aren dan sekam padi. Semakin naiknya kadar batubara dalam biobriket akan menyebabkan semakin tingginya temperatur pembakaran yang dihasilkan. Ini dikarenakan dengan semakin besarnya kadar batubara didalam biobriket, maka kandungan kalori biobriket juga akan semakin besar. Sedangkan semakin besar kandungan fixed karbon dalam biobriket, maka temperatur puncak akan dicapai dalam waktu yang lama.

\section{KESIMPULAN}

1. Ampas aren dan sekam padi memiliki sifat mudah terbakar, karena mengandung zat volatile matter yang tinggi. Sedangkan batubara memiliki sifat sulit terbakar, karena kandungan volatile matter-nya rendah dan fixed karbonnya tinggi, tetapi memiliki nilai kalor tinggi yang menghasilkan temperatur yang tinggi pula.

2. Biobriket campuran biomassa dan batubara akan menentukan karakteristik pembakaran. Biomassa yang mempunyai volatile matter yang tinggi dan batubara yang mempunyai nilai kalor yang tinggi akan saling mendukung dan menghasilkan pembakaran yang baik.

3. Biobriket dengan campuran $20 \%$ ampas aren, $20 \%$ sekam padi, dan $60 \%$ batubara bisa menjadi pilihan, karena mempunyai sifat mudah menyala dan temperaturnya tinggi.

\section{DAFTAR PUSTAKA}

[1] www.tekMIRA.esdm.go.id 8/8/2007

[2] Rachman, 2005, Pengaruh Variasi Jenis Biomass Ampas Tebu Dan Sekam Padi Terhadap Karakteristik Pembakaran Biobriket. Tugas Akhir, UMS, Surakarta.

[3] Raharjo, 2006, Mengenal Batubara. Artikel Iptek-Bidang Energi Dan Sumber Daya Alam.

[4] Sukandarrumidi,1995, Batubara dan Gambut, Gajah Mada University Press, Yogyakarta. 